\title{
Role of the axonal initial segment in psychiatric disorders: function, dysfunction, and intervention
}

\author{
Wei-Chun Jim Hsu ${ }^{1,2,3}$, Carol Lynn Nilsson ${ }^{4,5}$ and Fernanda Laezza ${ }^{4,6,7,8 *}$ \\ ${ }^{1}$ Department of Biochemistry and Molecular Biology, The University of Texas Medical Branch at Galveston, Galveston, TX, USA \\ ${ }^{2}$ Graduate Program in Biochemistry and Molecular Biology, The University of Texas Medical Branch at Galveston, Galveston, TX, USA \\ ${ }^{3}$ M.D.-Ph.D. Combined Degree Program, The University of Texas Medical Branch at Galveston, Galveston, TX, USA \\ ${ }^{4}$ Department of Pharmacology and Toxicology, The University of Texas Medical Branch at Galveston, Galveston, TX, USA \\ ${ }^{5}$ Sealy Center for Molecular Medicine, The University of Texas Medical Branch at Galveston, Galveston, TX, USA \\ ${ }^{6}$ Center for Addiction Research, The University of Texas Medical Branch at Galveston, Galveston, TX, USA \\ ${ }^{7}$ Center for Biomedical Engineering, The University of Texas Medical Branch at Galveston, Galveston, TX, USA \\ ${ }^{8}$ Mitchell Center for Neurodegenerative Diseases, The University of Texas Medical Branch at Galveston, Galveston, TX, USA
}

\section{Edited by:}

Sulie L. Chang, Seton Hall University, USA

\section{Reviewed by:}

Mikhail Pletnikov, Johns Hopkins

University, USA

Marisela Agudelo, Florida

International University, USA

\section{*Correspondence:}

Fernanda Laezza, Department of Pharmacology and Toxicology, The University of Texas Medical Branch at Galveston, 301 University Blvd,

Galveston, TX 77555, USA

e-mail: felaezza@utmb.edu
The progress of developing effective interventions against psychiatric disorders has been limited due to a lack of understanding of the underlying cellular and functional mechanisms. Recent research findings focused on exploring novel causes of psychiatric disorders have highlighted the importance of the axonal initial segment (AIS), a highly specialized neuronal structure critical for spike initiation of the action potential. In particular, the role of voltage-gated sodium channels, and their interactions with other protein partners in a tightly regulated macromolecular complex has been emphasized as a key component in the regulation of neuronal excitability. Deficits and excesses of excitability have been linked to the pathogenesis of brain disorders. Identification of the factors and regulatory pathways involved in proper AIS function, or its disruption, can lead to the development of novel interventions that target these mechanistic interactions, increasing treatment efficacy while reducing deleterious off-target effects for psychiatric disorders.

Keywords: axonal initial segment, psychiatric disorder, neuronal excitability, neuroplasticity, signaling pathways, RDoC

\section{DISORDERS OF THE BRAIN}

The human brain is known for its incredible complexity and heterogeneity. As such, it is susceptible to disorder and dysfunction, which in and of themselves are vastly diverse, ranging from frank physical lesions and trauma to complex changes in intracellular pathways (1). This extensive spectrum of brain disorders can generally be divided into two categories: neurologic and psychiatric. Neurologic disorders are those with a focal cause: an isolated traumatic, ischemic, neoplastic, or other insults. These include conditions such as ischemic strokes and epilepsy, and are characterized by a broadly robust understanding of the cause, if not the probable treatments. Psychiatric disorders, on the other hand, have classically been defined by the absence of an "organic lesion." Several of the major mood disorders such as depression, schizophrenia, and bipolar disorders fall under this category $(2,3)$. Importantly, for much of the history of psychiatry, treatments for such disorders have relied on empirical evidence. Physicians first tried treatment that had "worked in the past," and resorted to alternatives, also based on poorly generalizable empirical evidence, if that treatment failed.

Current widely used treatments against psychiatric disorders are fraught with mixed efficacy, poor patient tolerability, and high rates of relapse. The Sequenced Treatment Alternatives to Relieve Depression $\left(\operatorname{STAR}^{\star} \mathrm{D}\right)$ study $(4,5)$, one of the largest studies of treatment-resistant depression to date, reported that less than half of the enrolled patients achieved remission with a level 1 treatment protocol. More troubling yet, patients who progressed through later stages suffered progressively worse remission rates, and a substantial minority remained resistant to all conventionally used antidepressant treatments. For bipolar depression with psychosis, a particularly difficult form of depression to combat, treatment remains elusive. Conventional antidepressant medications, as demonstrated in the systematic treatment enhancement program for bipolar disorder (STEP-BD) study, can actually worsen outcomes and induce shifts to manic/hypomanic states (6). Furthermore, as demonstrated in the clinical antipsychotic trials of intervention effectiveness (CATIE) study (7), even current effective frontline treatments for disorders such as schizophrenia come with a myriad of side effects. These include significant weight gain, suicidal ideation, changes in sex drive, and gynecomastia, leading to a discontinuation rate of $74 \%$ in phase 1 of patient trials (8).

These observations and other small-scale clinical trials highlight the need for new approaches to develop medications against psychiatric disorders. The difficulty of managing treatmentresistant depression, along with the severe side effects of conventional psychiatric medications, underscores a need to understand their underlying fundamental molecular and cellular mechanisms of dysregulation, to allow the development of more targeted interventions $(9,10)$.

\section{FINDING MECHANISMS OF BRAIN DISORDERS AT THE SINGLE NEURON LEVEL}

The enduring shift away from conceptualizing mental disorders as simple alterations of chemistry or receptor dysregulation, into 
a more global picture of combined genetic predisposition and dysregulated signaling, has identified new opportunities for early intervention $(2,3,11)$. Genome-wide association studies (GWAS) looking for highly heritable genes for mental disorders, as well as monozygotic twin studies have provided researchers with sets of candidate genes that could be used as springboards for further in-depth studies (12). Advancement in biological tools, especially in the fields of high-throughput screening and next-generation sequencing, offers methods to rapidly filter thousands or even millions of candidate genes, compounds, or variants, vastly expanding the repertoire of data at researchers' disposal. In addition, ambitious projects such as the NIH Brain Initiative and Human Connectome Project (10) aim to develop tools to generate and visualize such datasets, applying "big data" analytics to datasets far beyond those typically studied in the laboratory.

That said, these top-down initiatives stress the need to understand the mechanisms of psychiatric disorders from a bottom-up perspective. Despite the advances made in identifying heritable risks and genetic targets of psychiatric disorders, we currently lack a fundamental understanding of their pathophysiology (13). The need to transition from treatments focused on clinical symptoms (the "low-hanging fruit" of psychiatry) into treatments that address their fundamental pathophysiology is urgent (2). Therefore, we need an in-depth understanding of the neuron, its critical components, and how their dysregulation can lead to psychiatric disorders.

\section{ROLE OF LARGE-SCALE GENETIC AND PROTEOMICS DATA IN IDENTIFYING NEW TARGETS RELEVANT FOR PSYCHIATRIC DISORDERS}

The completion of the human genome map (14) was an important milestone in scientific history because it enabled the association of genetic variations with disease and the generation of technologies such as transcriptomics and proteomics. Recently, several GWAS investigating risk factors for a number of psychiatric disorders have identified several significantly dysregulated genes encoding proteins at the axonal initial segment (AIS) of neurons (15-18). These novel findings emphasize the need to understand the physiological function of the AIS, and the implications of AIS disorder and dysfunction. Recent advances in human genetic research are essential for the advancement of psychiatric research, but may not be sufficient to understand every aspect of complex disease spectrums $(19,20)$. New methods to integrate gene activity and proteomic datasets, derived from biobank samples with associated clinical metadata, promise to provide the field with powerful tools to more precisely define the molecular phenotypes of psychiatric illnesses (21). These new methods have already been applied to neurodegenerative disorders such as Alzheimer's disease (20). Furthermore, systematic comparison between molecular and imaging data represents a new and powerful approach that is expected to define novel therapeutic targets and biomarkers of disease, and drug response $(22,23)$. However, applying large-scale genetic and proteomic approaches to psychiatric disorders requires bridging the knowledge gaps that exist in our understanding of the roles of AIS proteins at a single-cell level. The following sections will detail the role of the AIS in normal, as well as dysregulated, neurons.

\section{MOLECULAR COMPOSITION OF THE AIS}

In neurons, the AIS serves as a nexus, integrating information received from dendrites and converting it to an electrical output (Figure 1A). This highly regulated site, proximal to the soma and delineating the beginning of the neuronal axon, is characterized primarily by a high density of voltage-gated sodium (Nav) and potassium $(\mathrm{Kv})$ channels. These channels drive the initiation and propagation of the action potential (AP), and interact with several scaffolding and regulatory proteins to maintain electrical signaling $(24,25)$. Through the expression of specific scaffolding proteins and post-translational modification targeting, the AIS serves as a diffusion barrier to maintain the asymmetric distribution of axonal and dendritic proteins, ensuring that the neuron maintains cellular and electrical polarity (26-29). Due to this critical role in enforcing electrical signal directionality, disruptions or dysregulation of the molecular composition of the AIS is severely deleterious for proper neuronal function (30-32).

The AIS is highly enriched with several different isotypes of Nav and Kv channels, including the isoforms Nav1.1, 1.2, and 1.6 (33). Nav channels are transmembrane proteins comprising a large $\alpha$ subunit necessary and sufficient for $\mathrm{Na}^{+}$conduction, and regulatory $\beta$ subunits that can alter gating properties and localization (34). There are nine identifiable $\alpha$-subunits, which are composed of four domains, each with six membrane-spanning segments (S1-S6), and multiple intracellular segments engaged in protein-protein interactions (PPI). In the AIS, these $\alpha$-subunits exhibit distinct patterns of spatial and functional segregation (24, $35)$. The selective passage of $\mathrm{Na}^{+}$into the cell is regulated via voltage-dependent switching between open, closed, and inactivated conformations. In contrast, $\mathrm{Kv}$ channels allow the outward flow of potassium, producing a hyperpolarizing effect; they are highly diverse, residing in 12 distinct classes and dozens of identifiable isoforms (36). Similar to Nav, Kv channels exhibit voltagedependent conformational states that allow a regulated flux of $\mathrm{K}^{+}$ out of cells.

Many accessory proteins play a critical role in regulating both the trafficking and function of Nav and $\mathrm{Kv}$ channels at the AIS (Figure 2). One of the key scaffolding proteins that regulates localization of Nav and $\mathrm{Kv}$ channels to the AIS is ankyrin-G, one of a family of proteins that associate with several ion channels as well as integral membrane proteins (37-39). Ankyrin-G interacts with a cytoplasmic loop between domains II and III on Nav channels, and C3, a C-terminal domain containing an ankyrin-G binding loop on KCNQ2/3 Kv channels. Downregulation of ankyrin-G expression through siRNA blocks the clustering of $\mathrm{Na}^{+}$and $\mathrm{K}^{+}$ channels at the AIS (39-43). In addition, ankyrin-G recruits the critical scaffolding protein $\beta$-IV-spectrin, a process dependent on interactions between ankyrin-G and the spectrin repeat 15 (44), which stabilizes the clustering of Nav at the AIS (45) and plays an important role in the development of the nodes of Ranvier (46). Ankyrin-G also associates with one of the L1CAM family of cell adhesion molecules, neurofascin, which is alternatively spliced into several biologically relevant isoforms, including NF186, NF180, NF166, and NF155 (39). Crucially, the NF186 isoform is strongly enriched at the AIS and nodes of Ranvier, where it interacts with and stabilizes the Nav/ankyrin-G complex (47). FGF14, a member of the intracellular FGFs (iFGF; FGF11-13), is a non-secreted 


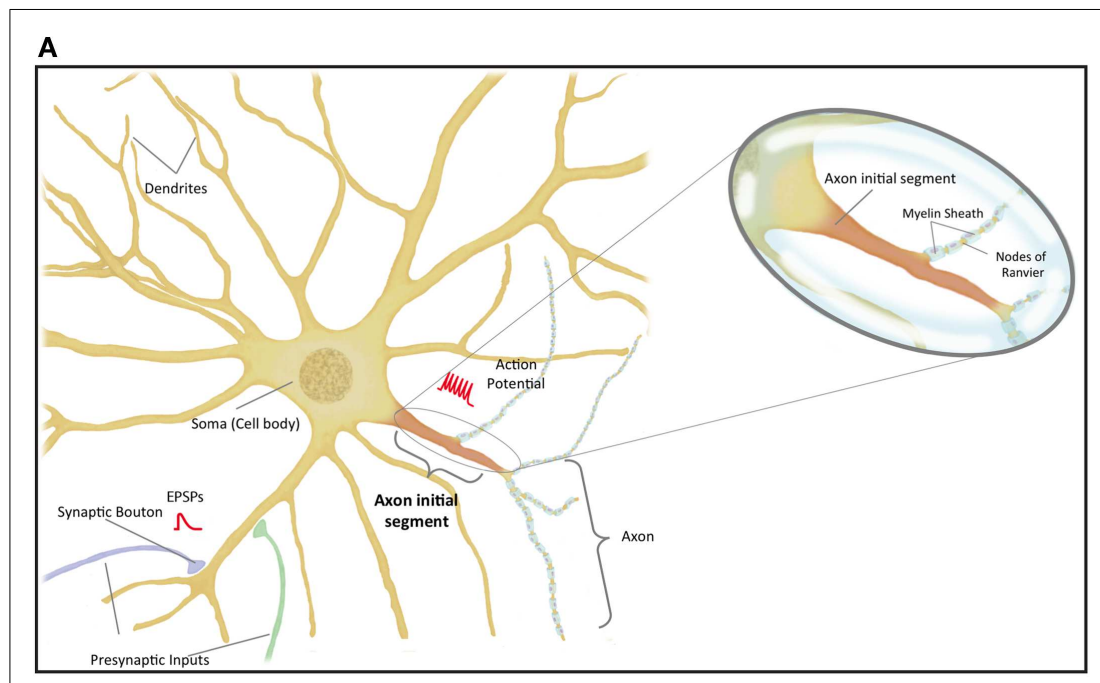

B

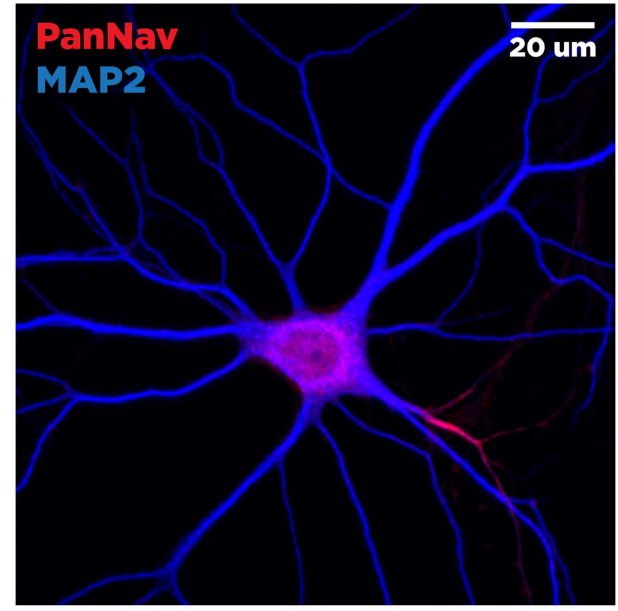

FIGURE 1 | Anatomy of the neuron. The brain comprised functional units called neurons, which process information both through electrical and chemical signals. Communication between neurons occurs through release of chemical mediators called neurotransmitters from synaptic boutons located distally on presynaptic inputs, which diffuses through a microscopic gap (the synapse) to receptors on the receiving (postsynaptic) neuron. Neurons display both functional and spatial polarity, with multiple dendrites receiving signals and typically a single axon for sending signals, both emerging from a central soma or cell body. In contrast, communication within a neuron occurs through transient changes in membrane voltages (the action potential), which are generated primarily through movement of ions through voltage-gated sodium (Nav) and potassium (Kv) channels. These channels are highly enriched at the axonal initial segment (AIS), a protein-dense region that functions as the site of action potential initiation. Ion channels are also found in high concentrations at the nodes of Ranvier, gaps in the insulating myelin sheath surrounding the axon that allow for rapid, or salutatory propagation of action potentials. (A) Schematic of the neuron. Excitatory postsynaptic potential (EPSP) and action potential (AP) shown in red, at the synaptic bouton and the axon initial segment, respectively. (B) Confocal microscopy of a primary rat hippocampal neuron, labeled with anti-PanNav (red) and anti-MAP2 (blue) antibody visualizing axonal and somatodendritic compartments, respectively. neuronal protein $(48,49)$ and an integral component of the AIS $(50,51)$. Through a direct interaction with the C-terminal tail of the Nav channel $\alpha$ subunit, FGF14 controls channel gating and Nav channel expression at the AIS. Loss of FGF14 function decreases $\mathrm{Na}^{+}$currents, reduces the expression of Nav channels at the AIS, and impairs neuronal excitability, and deletion of the $f g f 14$ gene in rodents impairs excitability and neuroplasticity (52-54). In addition, postsynaptic density-93 (PSD-93) functions as a scaffolding protein that mediates $\mathrm{K}^{+}$channel clustering at the AIS. Knockdown of PSD-93 in hippocampal neurons, as well as silencing in PSD-93 ${ }^{-1-}$ mice, disrupts Kv1 channel clustering at the AIS (55).

Additionally, several different kinases have been described to localize or exert control at the AIS. Protein kinase casein kinase 2 (CK2), a serine-threonine kinase expressed early in neuronal development (56), is highly enriched near the ankyrin-binding motif of Nav1.2 channels, where its phosphorylation of several serine residues (S1112, S1124, and S1126) is critical for interaction with ankyrin-G (57). Knockdown of CK2 impaired its own clustering at the AIS, as well as concentrations of ankyrin-G, $\mathrm{pI \kappa \textrm {B } \alpha}$, and Nav channels, suggesting a role for CK2 in axonal development (58). Calmodulin-dependent kinase (CaMKII), a serine/threonine kinase with diverse regulatory functions in ion transporter function, transcription, and cell death, is targeted to the AIS through interaction with the CaMKII-binding motif of $\beta$-IV-spectrin. A Cterminal truncation of $\beta$-IV-spectrin resulted in aberrant targeting of CaMKII, while localization of ankyrin-G and spectrin at the
AIS was normal (59). Cyclin-dependent kinase (Cdk)-dependent phosphorylation of the Kv2 $\beta$ subunit inhibits the interaction of $\mathrm{Kv} 2 \beta$ with microtubule proteins. Inhibition of Cdk with the pharmacological inhibitor roscovitine, enriched $\mathrm{Kv} \beta 2, \mathrm{Kv1}$, and the microtubule plus end-tracking protein EB1 at the AIS (60). Additionally, glycogen synthase kinase-3 (GSK-3), a multifunctional kinase important for neuronal survival and cellular response to stress (61), establishes neuronal polarity through signaling into pathways responsible for cytoskeletal organization and microtubule stabilization (62). It has also been implicated in the development of mood disorders including bipolar disorder, depression, and schizophrenia $(63,64)$. In fact lithium, one of the first psychotropic drugs identified and confirmed through clinical trials to be effective against bipolar disorder, does so in part through inhibition of GSK-3 (65-67). Although this mechanism is only one of many that underlie lithium's therapeutic potential, selective GSK-3 inhibitors, largely ATP competitors, have been reported to have an antidepressant-like effect in mice (68-71), with modulation of the upstream PI3K-Akt-GSK-3 pathway also playing a critical role $(72,73)$. Recently, it has been shown that inhibition of GSK-3 reduces interactions between FGF14 and Nav channels, and in hippocampal neurons, it induces redistribution of the FGF14Nav complex, causing a reversal of axo-dendritic polarity (74). These observations suggest the existence of a GSK-3-dependent signaling pathway in the maintenance of basal neuronal polarity; a pathway that might be impaired or modified in psychiatric disorders (75). 


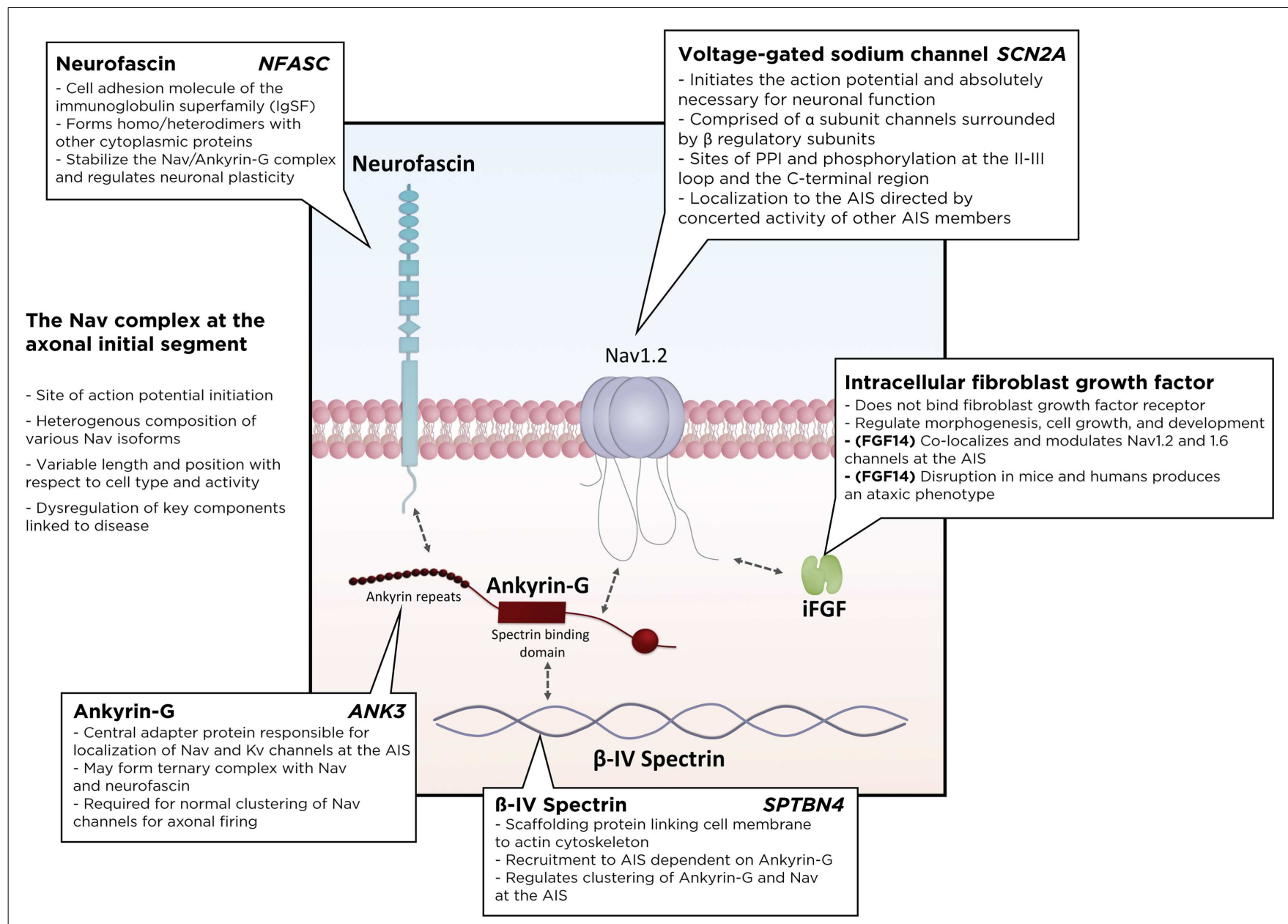

FIGURE 2 | Schematic of the Nav macromolecular complex at the axonal initial segment (AIS). Voltage-gated sodium channels form a tightly regulated complex with several critical regulatory and scaffolding proteins, including ankyrin-G, $\beta 4$-spectrin, neurofascin, and intracellular fibroblast growth factors. PPI, protein-protein interactions.

\section{FUNCTIONAL ROLE OF THE AIS}

There are several theories under consideration to explain why AIS is the site of AP initiation. Initial studies identified the AIS as a site of enrichment of $\mathrm{Nav}$ and $\mathrm{Kv}$ channels (76). However, later studies suggest that the more hyperpolarized voltage-dependence of Nav channels at the AIS better explains the low threshold of activation than channel density $(35,77,78)$. Other variable properties such as gating kinetics and ion channel post-translational modification may also underlie the low initiation threshold of the AIS through alteration of open channel probabilities (79).

The heterogeneous composition of the AIS is maintained through segregation of ion channel subtypes into distinct microdomains with consequences for neuronal function. Immunofluorescence experiments with Nav specific and PanNav antibodies have revealed three distinct domains of the AIS: a proximal portion of the AIS enriched in Nav1.1 and 1.2 channel subtypes, a medial portion with high levels of Kv1.2 channels, and a long distal portion enriched in lower-threshold Nav1.6 channels $(35,80)$. This segregation might underlie the mechanism behind the two forms of AP propagation: forward transmission through the action of Nav1.6 channels, and backpropagation through Nav1.2 channels. Confirming this hypothesis, the removal of Nav1.2 channels from the AIS region abrogated AP backpropagation (35).

The relative position of the AIS is cell type dependent and may be an important player in functional heterogeneity among various types of neurons $(25,81)$. Chronic depolarization of hippocampal neurons with high extracellular potassium has been observed to shift the components of the AIS, including Nav, $\beta$-IV-spectrin, neurofascin, and FGF14, distally from the soma with a corresponding decrease in firing rate (82). Furthermore, this shift was replicated via photostimulation of channelrhodopsin-2 transfected neurons and was reversible as well as frequency, interval, and $\mathrm{Ca}^{2+}$ dependent (82). These observations suggest that the relative position of the AIS along the axon may modulate neuronal excitability.

In summary, the diversity of AIS composition and localization may contribute to the diversity and specialization of function among different neuronal types. Disruption of AIS organization, 
due to injury, disease, or aging, can have profound effects for nervous system function, and may explain the pathophysiology of a variety of psychiatric disorders.

\section{FUNCTIONAL RELEVANCE OF THE AIS FOR PSYCHIATRIC DISORDERS}

The AIS is undoubtedly a crucial hub for neuronal function. Thus, dysfunction or dysregulation of AIS components predicts important consequences for neuronal function and has been identified as a causative component for many psychiatric and neurological disorders (Table 1).

Mutations of Nav have been linked with various neurological and psychiatric disorders. Dravet Syndrome is a form of severe myoclonic childhood-onset encephalopathy caused by de novo heterozygous mutations in Nav1.1 in which numerous epileptic phenotypes are seen including febrile, absence, myoclonic, and

Table 1 | A selection of human disorders associated with dysregulation of key AIS components.

\begin{tabular}{|c|c|c|}
\hline Class & Gene & Associated disorders \\
\hline \multirow{8}{*}{$\begin{array}{l}\text { Voltage- } \\
\text { gated } \\
\text { sodium } \\
\text { channels }\end{array}$} & \multirow[t]{5}{*}{ SCN1A } & $\begin{array}{l}\text { Dravet syndrome (severe myoclonic epilepsy } \\
\text { of infancy) }(83,86)\end{array}$ \\
\hline & & Sporadic autism and familial autism (92) \\
\hline & & Autism spectrum disorders (93) \\
\hline & & Familial hemiplegic migraine (95) \\
\hline & & Mesial temporal sclerosis (96) \\
\hline & SCN1B & Possibly linked to Dravet syndrome (86) \\
\hline & \multirow[t]{2}{*}{ SCN2A } & $\begin{array}{l}\text { Ohtahara syndrome (infantile epileptic } \\
\text { encephalopathy) (89) }\end{array}$ \\
\hline & & Autism spectrum disorders (92) \\
\hline \multirow[t]{4}{*}{ Ankyrins } & \multirow[t]{4}{*}{ ANK3 } & Bipolar disorder $(16,97,98)$ \\
\hline & & Schizophrenia $(99,101-103)$ \\
\hline & & Post-traumatic stress disorder (99) \\
\hline & & Late-onset Alzheimer's disease (104) \\
\hline \multirow[t]{5}{*}{ Spectrins } & All & Aging and Alzheimer's $(108,109)$ \\
\hline & SPTAN1 & West syndrome (infantile spasm) (112) \\
\hline & SPTBN2 & Spinocerebellar ataxia type $5(160)$ \\
\hline & \multirow[t]{2}{*}{ SPTBN4 } & Combined spherocytosis and autism (106) \\
\hline & & Auditory and motor neuropathies (107) \\
\hline \multirow{4}{*}{$\begin{array}{l}\text { L1 family } \\
\text { IgSFs }\end{array}$} & \multirow[t]{2}{*}{ NFASC } & Multiple sclerosis (116-118) \\
\hline & & $\begin{array}{l}\text { Central and peripheral demyelination disorder } \\
(116-118)\end{array}$ \\
\hline & \multirow[t]{2}{*}{ CHL1 } & Schizophrenia (120) \\
\hline & & Mental retardation (122-124) \\
\hline \multirow{4}{*}{$\begin{array}{l}\text { Intracellular } \\
\text { FGFs }\end{array}$} & \multirow{4}{*}{ FGF14 } & Spinocerebellar ataxia type $27(50,130,131)$ \\
\hline & & Paroxysmal dystonia (137) \\
\hline & & Cognitive impairment (138) \\
\hline & & Major depressive disorder (133) \\
\hline
\end{tabular}

atonic seizures (83). A mouse model with a C-terminal truncation of Nav1.1 reproduced severe ataxia, seizures, and premature death (84), and heterozygotes exhibited substantially reduced sodium current density in GABAergic inhibitory neurons (85). Thus, decreased GABAergic inhibition may result in increased seizurogenic currents, resulting in the severe seizures seen in myoclonic childhood-onset encephalopathy. In addition, generalized epilepsy with febrile seizures plus (GEFS+), a large set of autosomal dominant disorders that includes Dravet, encompass various mutations in $S C N 1 A$ and $S C N 1 B$ as well as genes encoding GABA receptors and calcium channels. Unlike patients with Dravet, who predominantly display truncation and missense mutations in the SCN1A gene, patients with GEFS+ display a much more variable clinical presentation (86). Additionally, missense Nav1.1 (87, 88), Nav1.2 (89), and Nav1.6 (90) mutations have been implicated in various forms of genetic epilepsies, and in fact Nav1.1 testing for genetic epilepsies is used in the clinic (91). Dysfunction of Nav has also been linked to autism. Early studies identified 38 significant SNPs in SCN1A, $S C N 2 A$, and $S C N 3 A$ in a cohort of 117 families with a history of genetic autism (92). More recently, genome sequencing of individuals with autism spectrum disorder have revealed multiple independent de novo SNP variants of Nav1.2 that are highly associated (93) and another group has identified a highly interconnected protein interaction network of de novo mutations, including disruptions in Nav1.1 in sporadic autism (94). Also, mutations of Nav1.1 have been observed in patients with familial hemiplegic migraine and epileptic phenotypes (95), and may be associated with hippocampal sclerosis (96). Due to the range of polymorphisms identified for Nav channels, further investigation into their relevance to the development of psychiatric disorders is needed.

In addition to Nav, dysfunction of the scaffolding protein ankyrin-G has been implicated in a number of psychiatric disorders. Ankyrin-G has been identified in GWAS as a potential risk gene for bipolar disorder with significantly associated SNPs in ANK3 as well as other bipolar disorder candidate genes $(16,97)$, including one that maps to a non-conservative amino acid change (98). Supporting the association of ANK3 with stress-related behaviors, a recent study has linked ANK3 SNPs with both post-traumatic stress disorder and externalizing (a measure identifying adult anti-sociality and substance abuse) in a cohort of military veterans (99). In addition, RNAi downregulation of ANK3 in the dentate gyrus of the mouse hippocampus decreased anxiety-related behaviors and increased activity during the light phase. These behaviors are consistent with increased stress and mood episodes in BD (100). ANK3 polymorphisms have also been associated with schizophrenia (101). Schizophrenic patients with ANK3 polymorphisms exhibit reduced ankyrin$\mathrm{G}$ density in the superficial dorsolateral prefrontal cortex and superior temporal gyrus compared with normal subjects. This has important consequences for pyramidal neuron connectivity, and speech and emotional processing (102, 103). Additionally, genome-wide studies support an association between ANK3 and late-onset Alzheimer's disease in the LOD-1 linkage region (104). In fact, vaccination with ankyrin-G in $\operatorname{arcA} \beta$ transgenic mice (a classic Alzheimer's model) reduced $\beta$-amyloid 
pathology in the brain and increased soluble levels of $A \beta$. In addition, hippocampal arcA $\beta$ neurons treated with monoclonal anti-AnkG antibodies displayed a reduction in the loss of dendritic spines (105).

Given the tight association between ankyrin-G and $\beta$-IVspectrin, dysregulation of spectrin expression or function can also be expected to contribute to several psychiatric disorders. Though research is currently lacking, the de novo microdeletion of a gene region containing $\beta$-IV-spectrin was observed in a patient with a combined autism/spherocytosis phenotype (106). In mice, truncation of $\beta$-IV-spectrin causes auditory as well as motor neuropathies, resulting in the autosomal recessive quivering phenotype (107). More broadly, spectrin catabolism through calpain-mediated cleavage, seen clinically in aged and patients with Alzheimer's disease $(108,109)$, has been associated with stimulation of $N$-methyl-D-aspartate (NMDA) receptors. This results in elevation of intracellular calcium levels as well as increased levels of spectrin breakdown products. These contribute to neuronal degeneration through disruption of intracellular transport and calcium toxicity $(110,111)$. Both $\alpha$ - and $\beta$-spectrin disruptions have been implicated in nervous system dysfunction. Heterozygous mutations in $\beta$-III-spectrin produce a slowly progressive, autosomal dominant spinocerebellar ataxia; a condition that exhibits the degeneration of cerebellar Purkinje cells and associated morphological abnormalities observed in a mouse knockout of $\beta$-III-spectrin. Mutations in $\alpha$-spectrins are associated with West Syndrome, an epilepsy disorder characterized by infantile spasms, atrophy of the corpus callosum and cerebellar vermis, and developmental regression (112). Further research is needed to determine the pathophysiology behind these disorders and identify the roles that non- $\beta$-IV spectrins may play in regulation of the AIS.

In addition to Nav and spectrin, ankyrin-G also interacts with L1CAM cell adhesion molecules. Isoforms of neurofascin and NrCAM, important members of the L1CAM family, colocalize with ankyrin-G at the AIS (113). Neurofascin plays a critical role in stabilizing complexes of Nav channels and ankyrin-G $(47,114)$, so defects in neurofascin will adversely affect neuronal function. Knockdown of neurofascin in adult rat brain impairs GABAergic expression at synapses localized at the AIS, which suggests its function in modulating axo-axonal innervation (114). Furthermore, inactivation of neuronal neurofascin (NF186) in adult mice results in AIS degeneration, Purkinje cell dysfunction, and impaired motor learning (115). In human patients, axonal injury characteristic of multiple sclerosis (MS) and other demyelination disorders is associated with increased concentrations of autoantibodies against both NF155 and NF186, which are present in inflammation involving complement deposit, microglial activation, and ultimately axonal injury (116-118). More broadly, defects in the L1 gene family, which encodes various cell adhesion molecules including neurofascin (119), have been observed in a variety of neurological and psychiatric disorders. SNPs in CHL1 are associated with an increased risk of schizophrenia (120) Postmortem analysis of hippocampus and amygdala from schizophrenic patients revealed decreased polysialylated neural cell adhesion molecule (PSA-NCAM) expression in parallel with decreased GAD67 and increased VGLUT1 levels in white matter (121).
In addition, patients with chromosome $3 p$ aberrations (which include several brain-expressed genes including contactin and CHL1) present clinically with mental retardation. A subset of those also exhibit physical features such as skeletal defects and facial dysmorphism (122-124). Supporting the role of CHL1 in mental retardation, Chl1-heterozygote and homozygote mice exhibit a gene dosing effect. $\mathrm{Chl1}^{-1-}$ mice display altered exploratory patterns in the Morris water maze test, increased sociality, and reduced aggression (125), suggesting that processes involving cognition and spatial memory are disrupted. In addition, phosphorylation of L1 increases its association with doublecortin, which is important for neuronal migration (126), and is downstream of MAP kinase pathways (127). This suggests that ERK-dependent signaling may promote neurite growth through downregulation of L1 and ankyrin binding $(128,129)$. These observations highlight the diversity of the L1 gene family, and the need for more research into how other components of the L1 family interact at the level of the AIS.

Mutations of the intracellular fibroblast growth factor FGF14 have been associated with hereditary spinocerebellar ataxia (130, 131), a debilitating childhood-onset condition characterized by postural tremor, slowly progressive ataxia, and cognitive deficits. Specifically in SCA27, the FGF14 ${ }^{\mathrm{F} 145 \mathrm{~S}}$ mutation decreased Nav currents and reduced neuronal excitability in hippocampal neurons by disrupting the FGF14:Nav interaction by a dominant negative inhibition of the FGF14 wild-type form (50,131). Further analysis of the P149Q polymorphism on a closely related homolog, FGF12, revealed a loss of pairwise specificity with the C-terminal end of Nav1.1 and subsequent loss of $\mathrm{Na}^{+}$channel function modulation, suggesting that mutations in this region may dysregulate neuronal excitability (132). Additionally, a genome-wide study performed on a Dutch major depressive disorder cohort identified SNPs covering seven candidate genes including FGF14 (18). Previous studies have implicated extracellular FGF activity in stress and major depressive disorder (133). In fact, increases in hippocampal FGF activity may be one of the mechanisms of antidepressants such as fluoxetine, desipramine, and mianserin (134-136). In mice, targeted disruption of FGF14 produces severe ataxia, paroxysmal dystonia, and cognitive impairment $(137,138)$, with neurons that exhibit severe impairments in synaptic plasticity (53) and neuronal excitability (52). Significantly, the assembly and trafficking of FGF14 itself is controlled via a GSK-3-dependent signaling pathway (74) that may critically regulate excitability through PPI at the level of the Nav complex. Additionally, the distribution of FGF14 is Nav channel dependent. Deletion of the Nav1.6 $\alpha$ subunit in mouse Purkinje neurons markedly increases FGF14 levels in the AIS, in parallel with increased expression of Nav1.1 and $\beta$-IV-spectrin (139). As a result, through interactions with macromolecular complexes at the AIS, FGF14 plays an important and underappreciated role in the regulation of $\mathrm{Na}+$ channel activity.

\section{AIS TARGETING AS A PHARMACOLOGICAL STRATEGY}

Given the association between defects at the level of AIS and subsequent impairment of neuronal function that leads to the development of several important neurological and mental disorders, interventions directed at restoring AIS function may be more 
effective. Targeting AIS function would allow for the development of highly specific, efficacious compounds with significantly reduced off-target effects and enhanced clinical outcomes (13, 140, 141). Given the importance of the molecular composition of the AIS to disease, selective targeting of PPI at the AIS may deliver a new generation of treatments against psychiatric disorders.

\section{IMPROVING DIVERSITY THROUGH PROTEIN-PROTEIN INTERACTIONS}

Inhibition of PPI remains a novel and increasingly attractive area of drug design. Although nascent, it has the potential to tremendously expand the repertoire of targets available for the pharmaceutical industry $(142,143)$. Through the engineering of small molecules or peptidomimetics $(144,145)$ that interact with and disrupt specific protein-protein interfaces, the effects of the inhibitor on the signaling network of the cell would be restricted from $n$ edges ( $n=$ number of potential PPI between the targeted protein and the entire proteome) to a single edge. This would vastly increase the potential specificity without diminishing effectiveness. In addition, selective targeting of protein surfaces prevents global disruption of protein expression levels, which may upregulate alternative and compensatory pathways that reverse treatment effects and replace critical "disease-promoting" factors, leading to relapse (144). In the context of dysregulation at the AIS, this targeted multi-protein approach has the potential to restore function as a consequence of a specific deficiency while having a minimal impact on other properly functioning pathways.

Approaches to discover PPI of interest are cooperative, and include yeast two-hybrid systems, RNAi interference, protein fragment complementation, mass spectrometry, and direct coimmunoprecipitation. Large-scale studies using high-throughput technologies in combination with algorithmic approaches have identified hundreds of thousands of protein interactions based on structural evidence and biochemical assays (146, 147). However, the design of small molecules to exploit these PPI presents an entirely new set of challenges, especially if the PPI are part of ion channel complexes, as is the case at the AIS (143). Many studies use computational modeling in conjunction with HTS approaches to screen databases of "drug-like" compounds for molecules that bind to "hot-spots"; regions within the protein near the proteinprotein interface. Alternative approaches could include the study of allosteric PPI modulators, compounds that bind at a site distant from the interaction interface that induce conformation changes which alter the PPI, as well as fragment-based approaches that involve searching two separate compounds joined by a linker to better probe chemical space $(148,149)$. However, the difficulty of translating biochemical assays to actual human therapies manifests as concerns in stability, pharmacokinetics/bioavailability, and toxicity, and poses a substantial barrier toward effective therapies that target the PPI (144).

Nonetheless, therapeutic targeting of PPI is an intensive area of interest in oncology, with preliminary studies in brain disorders. A number of BCL-2/BH3 PPI inhibitors such as GX15-070 and AT-101 are used in early clinical trials for a variety of solid tumors, including lung carcinoma and GIST, with more expectation (150, 151). Utilizing a multiple ligand simultaneous docking (MLSD) model, a group has identified raloxifene and bazedoxifene as potent inhibitors of the IL-6/GP130 interface, a critical step in the
STAT3-mediated pathway of cancer progression (152). In the context of cerebral ischemia and neuropathic pain, GABAB receptors are often excessively upregulated $(153,154)$, and small peptides interfering with GABA-interacting proteins such as 14-3-3 may selectively restore normal GABA function without affecting the GABA receptors not implicated in disease $(155,156)$. Disruption of metabotropic glutamate receptor (mGluR7a) interaction with proteins interacting with kinase 1 (PICK1) has been shown to induce the absence of seizures in rodents, suggesting that small molecules that stabilize this interaction could be potential therapeutics against epilepsy (157). Additionally, interaction of the serotonin $5 \mathrm{HT} 2 \mathrm{C}$ receptor with multiple PDZ (MPDZ), a gene found to be dysregulated in physiological drug dependence (158), has been explored as a potential avenue of research in addiction phenotypes, and small molecule inhibitors of the MPDZ-5HT2C interaction have been developed (159).

These early successes highlight the potential for harnessing PPI at the AIS as a novel approach toward better interventions against psychiatric disorders. Through the engineering of novel therapeutics that target dysregulation at the interaction level, versus the protein level, there is much potential for greater specificity and diversity in the design of useful psychiatric treatments.

\section{CONCLUSION}

Despite the immense challenges in treating patients with psychiatric disorders, next-generation treatments based on rational understanding of the underlying mechanisms of dysregulation hold much promise. Early, top-down high-throughput studies to identify focal points of dysfunction, as well as bottom-up reductionist studies of the core components of neurons, including the AIS, will invariably lead to a better understanding of the pathophysiology behind psychiatric disorders. Whether this new-found understanding leads to concrete treatments for psychiatric disorders - the middle-aged mom of two suffering from yet another relapse of depression; the hard-working, successful executive crippled by a decade-long struggle with schizophrenia; the college freshman terrified by yet another manic episode - remains to be seen, but the urgent need for more effective, less deleterious treatments is undeniable.

\section{METHODS}

\section{NEURONAL CULTURES AND CONFOCAL MICROSCOPY}

Primary hippocampal cultures were obtained from E18 rat embryos using Banker's method and processed for immunofluorescence as previously described (74). The image displayed in Figure 1B was obtained using rabbit anti-PanNav and chicken anti-microtubule-associated protein 2 (MAP2) primary antibodies followed by incubation with appropriate Alexa-conjugated secondary antibodies for immunofluorescence visualization. Confocal images were obtained at a magnification of $63 \times$ with a Zeiss LSM-510 Meta confocal microscope.

\section{ACKNOWLEDGMENTS}

Wei-Chun Jim Hsu: Supported by the Sealy Center for Molecular Medicine, UTMB, TX. Carol L. Nilsson: Received grant support from the Cancer Prevention Research Institute of Texas (R1221). Fernanda Laezza, M.D., Ph.D.: Received grant support 
from National Institutes of Health Grant R01MH095995 from NIMH, FL.

\section{REFERENCES}

1. Insel TR, Quirion R. Psychiatry as a clinical neuroscience discipline. JAMA (2005) 294:2221-4. doi:10.1001/jama.294.17.2221

2. Cuthbert BN, Insel TR. Toward the future of psychiatric diagnosis: the seven pillars of RDoC. BMC Med (2013) 11:126. doi:10.1186/1741-7015-11-126

3. Insel TR. The NIMH research domain criteria (RDoC) project: precision medicine for psychiatry. Am J Psychiatry (2014) 171:395-7. doi:10.1176/appi.ajp. 2014.14020138

4. Rush AJ, Fava M, Wisniewski SR, Lavori PW, Trivedi MH, Sackeim HA, et al. Sequenced treatment alternatives to relieve depression $\left(\operatorname{STAR}^{*} \mathrm{D}\right)$ : rationale and design. Control Clin Trials (2004) 25:119-42. doi:10.1016/S0197-2456(03) 00112-0

5. Pigott HE, Leventhal AM, Alter GS, Boren JJ. Efficacy and effectiveness of antidepressants: current status of research. Psychother Psychosom (2010) 79:267-79. doi:10.1159/000318293

6. Perlis RH, Ostacher MJ, Patel JK, Marangell LB, Zhang H, Wisniewski SR, et al. Predictors of recurrence in bipolar disorder: primary outcomes from the systematic treatment enhancement program for bipolar disorder (STEP-BD). Am J Psychiatry (2006) 163:217-24. doi:10.1176/appi.ajp.163.2.217

7. Stroup TS, McEvoy JP, Swartz MS, Byerly MJ, Glick ID, Canive JM, et al. The national institute of mental health clinical antipsychotic trials of intervention effectiveness (CATIE) project: schizophrenia trial design and protocol development. Schizophr Bull (2003) 29:15-31. doi:10.1093/oxfordjournals.schbul. a006986

8. Lieberman JA, Stroup TS. The NIMH-CATIE Schizophrenia Study: what did we learn? Am J Psychiatry (2011) 168:770-5. doi:10.1176/appi.ajp.2011.11010039

9. Insel TR, Landis SC. Twenty-five years of progress: the view from NIMH and NINDS. Neuron (2013) 80:561-7. doi:10.1016/j.neuron.2013.09.041

10. Insel TR, Landis SC, Collins FS. Research priorities. The NIH brain initiative. Science (2013) 340:687-8. doi:10.1126/science. 1239276

11. Insel TR. Rethinking schizophrenia. Nature (2010) 468:187-93. doi:10.1038/ nature 09552

12. Lonsdale J, Thomas J, Salvatore M, Phillips R, Lo E, Shad S, et al. The genotypetissue expression (GTEx) project. Nat Genet (2013) 45:580-5. doi:10.1038/ng. 2653

13. Insel TR. Next-generation treatments for mental disorders. Sci Transl Med (2012) 4:155ps19. doi:10.1126/scitranslmed.3004873

14. Venter JC, Adams MD, Myers EW, Li PW, Mural RJ, Sutton GG, et al. The sequence of the human genome. Science (2001) 291:1304-51. doi:10.1126/ science. 1058040

15. Leussis MP, Madison JM, Petryshen TL. Ankyrin 3: genetic association with bipolar disorder and relevance to disease pathophysiology. Biol Mood Anxiety Disord (2012) 2:18. doi:10.1186/2045-5380-2-18

16. Smith EN, Bloss CS, Badner JA, Barrett T, Belmonte PL, Berrettini W, et al. Genome-wide association study of bipolar disorder in European American and African American individuals. Mol Psychiatry (2009) 14:755-63. doi:10.1038/mp.2009.43

17. Szczepankiewicz A. Evidence for single nucleotide polymorphisms and their association with bipolar disorder. Neuropsychiatr Dis Treat (2013) 9:1573-82. doi:10.2147/NDT.S28117

18. Verbeek EC, Bakker IM, Bevova MR, Bochdanovits Z, Rizzu P, Sondervan D, et al. A fine-mapping study of 7 top scoring genes from a GWAS for major depressive disorder. PLoS One (2012) 7:e37384. doi:10.1371/journal. pone. 0037384

19. Landgren S, von Otter M, Palmer MS, Zetterstrom C, Nilsson S, Skoog I, et al. A novel ARC gene polymorphism is associated with reduced risk of Alzheimer's disease. J Neural Transm (2012) 119:833-42. doi:10.1007/s00702012-0823-x

20. Skillback T, Zetterberg H, Blennow K, Mattsson N. Cerebrospinal fluid biomarkers for Alzheimer disease and subcortical axonal damage in 5,542 clinical samples. Alzheimers Res Ther (2013) 5:47. doi:10.1186/alzrt212

21. Emmett MR, Kroes RA, Moskal JR, Conrad CA, Priebe W, Laezza F, et al. Integrative biological analysis for neuropsychopharmacology. Neuropsychopharmacology (2014) 39:5-23. doi:10.1038/npp.2013.156
22. Hampel H, Bürger K, Teipel SJ, Bokde ALW, Zetterberg H, Blennow K. Core candidate neurochemical and imaging biomarkers of Alzheimer's disease. Alzheimers Dement (2008) 4:38-48. doi:10.1016/j.jalz.2007.08.006

23. Shariatgorji M, Svenningsson P, Andren PE. Mass spectrometry imaging, an emerging technology in neuropsychopharmacology. Neuropsychopharmacology (2014) 39:34-49. doi:10.1038/npp.2013.215

24. Kole MH, Ilschner SU, Kampa BM, Williams SR, Ruben PC, Stuart GJ. Action potential generation requires a high sodium channel density in the axon initial segment. Nat Neurosci (2008) 11:178-86. doi:10.1038/nn2040

25. Lorincz A, Nusser Z. Cell-type-dependent molecular composition of the axon initial segment. J Neurosci (2008) 28:14329-40. doi:10.1523/JNEUROSCI. 4833-08.2008

26. Konishi Y, Setou M. Tubulin tyrosination navigates the kinesin-1 motor domain to axons. Nat Neurosci (2009) 12:559-67. doi:10.1038/nn.2314

27. Rasband MN. The axon initial segment and the maintenance of neuronal polarity. Nat Rev Neurosci (2010) 11:552-62. doi:10.1038/nrn2852

28. Song AH, Wang D, Chen G, Li Y, Luo J, Duan S, et al. A selective filter for cytoplasmic transport at the axon initial segment. Cell (2009) 136:1148-60. doi:10.1016/j.cell.2009.01.016

29. Winckler B, Forscher P, Mellman I. A diffusion barrier maintains distribution of membrane proteins in polarized neurons. Nature (1999) 397:698-701. doi:10.1038/17806

30. Harty RC, Kim TH, Thomas EA, Cardamone L, Jones NC, Petrou S, et al. Axon initial segment structural plasticity in animal models of genetic and acquired epilepsy. Epilepsy Res (2013) 105:272-9. doi:10.1016/j.eplepsyres.2013.03.004

31. Puthussery T, Venkataramani S, Gayet-Primo J, Smith RG, Taylor WR. NaV1.1 channels in axon initial segments of bipolar cells augment input to magnocellular visual pathways in the primate retina. J Neurosci (2013) 33:16045-59. doi:10.1523/JNEUROSCI.1249-13.2013

32. Royeck M, Horstmann MT, Remy S, Reitze M, Yaari Y, Beck H. Role of axonal NaV1.6 sodium channels in action potential initiation of CA1 pyramidal neurons. J Neurophysiol (2008) 100:2361-80. doi:10.1152/jn.90332.2008

33. Grubb MS, Shu Y, Kuba H, Rasband MN, Wimmer VC, Bender KJ. Short- and long-term plasticity at the axon initial segment. J Neurosci (2011) 31:16049-55. doi:10.1523/JNEUROSCI.4064-11.2011

34. Patino GA, Isom LL. Electrophysiology and beyond: multiple roles of $\mathrm{Na}+$ channel beta subunits in development and disease. Neurosci Lett (2010) 486:53-9. doi:10.1016/j.neulet.2010.06.050

35. Hu W, Tian C, Li T, Yang M, Hou H, Shu Y. Distinct contributions of $\mathrm{Na}(\mathrm{v}) 1.6$ and $\mathrm{Na}(\mathrm{v}) 1.2$ in action potential initiation and backpropagation. Nat Neurosci (2009) 12:996-1002. doi:10.1038/nn.2359

36. Gutman GA, Chandy KG, Grissmer S, Lazdunski M, McKinnon D, Pardo LA, et al. International union of pharmacology. LIII. Nomenclature and molecular relationships of voltage-gated potassium channels. Pharmacol Rev (2005) 57:473-508. doi:10.1124/pr.57.4.10

37. Bennett V, Lambert S. Physiological roles of axonal ankyrins in survival of premyelinated axons and localization of voltage-gated sodium channels. J Neurocytol (1999) 28:303-18. doi:10.1023/A:1007005528505

38. Bennett V, Lambert S, Davis JQ, Zhang X. Molecular architecture of the specialized axonal membrane at the node of Ranvier. Soc Gen Physiol Ser (1997) 52:107-20.

39. Zhou D, Lambert S, Malen PL, Carpenter S, Boland LM, Bennett V. AnkyrinG is required for clustering of voltage-gated $\mathrm{Na}$ channels at axon initial segments and for normal action potential firing. J Cell Biol (1998) 143:1295-304. doi:10.1083/jcb.143.5.1295

40. Barry J, Gu Y, Jukkola P, O’Neill B, Gu H, Mohler PJ, et al. Ankyrin-G directly binds to kinesin- 1 to transport voltage-gated $\mathrm{Na}+$ channels into axons. Dev Cell (2014) 28:117-31. doi:10.1016/j.devcel.2013.11.023

41. Garrido JJ, Giraud P, Carlier E, Fernandes F, Moussif A, Fache MP, et al. A targeting motif involved in sodium channel clustering at the axonal initial segment. Science (2003) 300:2091-4. doi:10.1126/science.1085167

42. Lemaillet G, Walker B, Lambert S. Identification of a conserved ankyrinbinding motif in the family of sodium channel alpha subunits. J Biol Chem (2003) 278:27333-9. doi:10.1074/jbc.M303327200

43. Pan Z, Kao T, Horvath Z, Lemos J, Sul JY, Cranstoun SD, et al. A common ankyrin-G-based mechanism retains KCNQ and NaV channels at electrically active domains of the axon. J Neurosci (2006) 26:2599-613. doi:10.1523/ JNEUROSCI.4314-05.2006 
44. Yang Y, Ogawa Y, Hedstrom KL, Rasband MN. BetaIV spectrin is recruited to axon initial segments and nodes of Ranvier by ankyrinG. J Cell Biol (2007) 176:509-19. doi:10.1083/jcb.200610128

45. Komada M, Soriano P. [Beta]IV-spectrin regulates sodium channel clustering through ankyrin-G at axon initial segments and nodes of Ranvier. J Cell Biol (2002) 156:337-48. doi:10.1083/jcb.200110003

46. Jenkins SM, Bennett V. Developing nodes of Ranvier are defined by ankyrin-G clustering and are independent of paranodal axoglial adhesion. Proc Natl Acad Sci U S A (2002) 99:2303-8. doi:10.1073/pnas.042601799

47. Kriebel M, Wuchter J, Trinks S, Volkmer H. Neurofascin: a switch between neuronal plasticity and stability. Int J Biochem Cell Biol (2012) 44:694-7. doi:10.1016/j.biocel.2012.01.012

48. Olsen SK, Garbi M, Zampieri N, Eliseenkova AV, Ornitz DM, Goldfarb M, et al. Fibroblast growth factor (FGF) homologous factors share structural but not functional homology with FGFs. J Biol Chem (2003) 278:34226-36. doi:10.1074/jbc.M303183200

49. Smallwood PM, Munoz-Sanjuan I, Tong P, Macke JP, Hendry SH, Gilbert DJ, et al. Fibroblast growth factor (FGF) homologous factors: new members of the FGF family implicated in nervous system development. Proc Natl Acad Sci U S A (1996) 93:9850-7. doi:10.1073/pnas.93.18.9850

50. Laezza F, Gerber BR, Lou JY, Kozel MA, Hartman H, Craig AM, et al. The FGF14(F145S) mutation disrupts the interaction of FGF14 with voltage-gated $\mathrm{Na}+$ channels and impairs neuronal excitability. J Neurosci (2007) 27:12033-44. doi:10.1523/JNEUROSCI.2282-07.2007

51. Lou JY, Laezza F, Gerber BR, Xiao M, Yamada KA, Hartmann H, et al. Fibroblast growth factor 14 is an intracellular modulator of voltage-gated sodium channels. J Physiol (2005) 569:179-93. doi:10.1113/jphysiol.2005.097220

52. Goldfarb M, Schoorlemmer J, Williams A, Diwakar S, Wang Q, Huang X, et al. Fibroblast growth factor homologous factors control neuronal excitability through modulation of voltage-gated sodium channels. Neuron (2007) 55:449-63. doi:10.1016/j.neuron.2007.07.006

53. Xiao M, Xu L, Laezza F, Yamada K, Feng S, Ornitz DM. Impaired hippocampal synaptic transmission and plasticity in mice lacking fibroblast growth factor 14. Mol Cell Neurosci (2007) 34:366-77. doi:10.1016/j.mcn.2006.11.020

54. Yan H, Pablo JL, Pitt GS. FGF14 regulates presynaptic Ca2+ channels and synaptic transmission. Cell Rep (2013) 4:66-75. doi:10.1016/j.celrep.2013.06.012

55. Ogawa Y, Horresh I, Trimmer JS, Bredt DS, Peles E, Rasband MN. Postsynaptic density-93 clusters Kv1 channels at axon initial segments independently of Caspr2. J Neurosci (2008) 28:5731-9. doi:10.1523/JNEUROSCI.4431-07.2008

56. Moreno FJ, Díaz-Nido J, Jiménez JS, Avila J. Distribution of CK2, its substrate MAP1B and phosphatases in neuronal cells. Mol Cell Biochem (1999) 191:201-5. doi:10.1023/A:1006836211318

57. Bréchet A, Fache MP, Brachet A, Ferracci G, Baude A, Irondelle M, et al. Protein kinase CK2 contributes to the organization of sodium channels in axonal membranes by regulating their interactions with ankyrin G. J Cell Biol (2008) 183:1101-14. doi:10.1083/jcb.200805169

58. Sanchez-Ponce D, Muñoz A, Garrido JJ. Casein kinase 2 and microtubules control axon initial segment formation. Mol Cell Neurosci (2011) 46:222-34. doi:10.1016/j.mcn.2010.09.005

59. Hund TJ, Koval OM, Li J, Wright PJ, Qian L, Snyder JS, et al. A $\beta($ IV)spectrin/CaMKII signaling complex is essential for membrane excitability in mice. J Clin Invest (2010) 120:3508-19. doi:10.1172/JCI43621

60. Vacher H, Yang JW, Cerda O, Autillo-Touati A, Dargent B, Trimmer JS. Cdkmediated phosphorylation of the $\mathrm{Kv} \beta 2$ auxiliary subunit regulates Kv1 channel axonal targeting. J Cell Biol (2011) 192:813-24. doi:10.1083/jcb.201007113

61. Jope RS, Yuskaitis CJ, Beurel E. Glycogen synthase kinase-3 (GSK3): inflammation, diseases, and therapeutics. Neurochem Res (2007) 32:577-95. doi:10. 1007/s11064-006-9128-5

62. Kim J, Yang M, Kim SH, Kim JC, Wang H, Shin T, et al. Possible role of the glycogen synthase kinase-3 signaling pathway in trimethyltin-induced hippocampal neurodegeneration in mice. PLoS One (2013) 8:e70356. doi:10.1371/journal. pone.0070356

63. Jope RS, Roh MS. Glycogen synthase kinase-3 (GSK3) in psychiatric diseases and therapeutic interventions. Curr Drug Targets (2006) 7:1421-34. doi:10.2174/1389450110607011421

64. Li X, Frye MA, Shelton RC. Review of pharmacological treatment in mood disorders and future directions for drug development. Neuropsychopharmacology (2012) 37:77-101. doi:10.1038/npp.2011.198
65. Chiu CT, Chuang DM. Molecular actions and therapeutic potential of lithium in preclinical and clinical studies of CNS disorders. Pharmacol Ther (2010) 128:281-304. doi:10.1016/j.pharmthera.2010.07.006

66. Malhi GS, Tanious M, Das P, Berk M. The science and practice of lithium therapy. Aust N Z J Psychiatry (2012) 46:192-211. doi:10.1177/0004867412437346

67. Malhi GS, Tanious M, Das P, Coulston CM, Berk M. Potential mechanisms of action of lithium in bipolar disorder. Current understanding. CNS Drugs (2013) 27:135-53. doi:10.1007/s40263-013-0039-0

68. Beaulieu JM, Sotnikova TD, Yao WD, Kockeritz L, Woodgett JR, Gainetdinov $\mathrm{RR}$, et al. Lithium antagonizes dopamine-dependent behaviors mediated by an AKT/glycogen synthase kinase 3 signaling cascade. Proc Natl Acad Sci U S A (2004) 101:5099-104. doi:10.1073/pnas.0307921101

69. Chen L, Zhou W, Chen PC, Gaisina I, Yang S, Li X. Glycogen synthase kinase3 beta is a functional modulator of serotonin-1B receptors. Mol Pharmacol (2011) 79:974-86. doi:10.1124/mol.111.071092

70. Gould TD, Einat H, Bhat R, Manji HK. AR-A014418, a selective GSK-3 inhibitor, produces antidepressant-like effects in the forced swim test. Int J Neuropsychopharmacol (2004) 7:387-90. doi:10.1017/S1461145704004535

71. Rosa AO, Kaster MP, Binfare RW, Morales S, Martin-Aparicio E, Navarro-Rico ML, et al. Antidepressant-like effect of the novel thiadiazolidinone NP031115 in mice. Prog Neuropsychopharmacol Biol Psychiatry (2008) 32:1549-56. doi: 10.1016/j.pnpbp.2008.05.020

72. Budni J, Lobato KR, Binfare RW, Freitas AE, Costa AP, Martin-de-Saavedra MD, et al. Involvement of PI3K, GSK-3beta and PPARgamma in the antidepressantlike effect of folic acid in the forced swimming test in mice. J Psychopharmacol (2012) 26:714-23. doi:10.1177/0269881111424456

73. Pan JQ, Lewis MC, Ketterman JK, Clore EL, Riley M, Richards KR, et al. AKT kinase activity is required for lithium to modulate mood-related behaviors in mice. Neuropsychopharmacology (2011) 36:1397-411. doi:10.1038/npp. 2011.24

74. Shavkunov AS, Wildburger NC, Nenov MN, James TF, Buzhdygan TP, PanovaElektronova NI, et al. The fibroblast growth factor 14/voltage-gated sodium channel complex is a new target of glycogen synthase kinase 3 (GSK3). J Biol Chem (2013) 288:19370-85. doi:10.1074/jbc.M112.445924

75. Wildburger NC, Laezza F. Control of neuronal ion channel function by glycogen synthase kinase-3: new prospective for an old kinase. Front Mol Neurosci (2012) 5:80. doi:10.3389/fnmol.2012.00080

76. Catterall WA. Localization of sodium channels in cultured neural cells. J Neurosci (1981) 1:777-83.

77. Bender KJ, Trussell LO. Axon initial segment Ca2+ channels influence action potential generation and timing. Neuron (2009) 61:259-71. doi:10.1016/j. neuron.2008.12.004

78. Colbert CM, Pan E. Ion channel properties underlying axonal action potential initiation in pyramidal neurons. Nat Neurosci (2002) 5:533-8. doi:10.1038/ nn0602-857

79. Baek JH, Cerda O, Trimmer JS. Mass spectrometry-based phosphoproteomics reveals multisite phosphorylation on mammalian brain voltage-gated sodium and potassium channels. Semin Cell Dev Biol (2011) 22:153-9. doi:10.1016/j. semcdb.2010.09.009

80. Van Wart A, Trimmer JS, Matthews G. Polarized distribution of ion channels within microdomains of the axon initial segment. J Comp Neurol (2007) 500:339-52. doi:10.1002/cne.21173

81. Kuba H, Adachi R, Ohmori H. Activity-dependent and activity-independent development of the axon initial segment. J Neurosci (2014) 34:3443-53. doi:10.1523/JNEUROSCI.4357-13.2014

82. Grubb MS, Burrone J. Activity-dependent relocation of the axon initial segment fine-tunes neuronal excitability. Nature (2010) 465:1070-4. doi:10.1038/ nature09160

83. Claes L, Del-Favero J, Ceulemans B, Lagae L, Van Broeckhoven C, De Jonghe P. De novo mutations in the sodium-channel gene SCN1A cause severe myoclonic epilepsy of infancy. Am J Hum Genet (2001) 68:1327-32. doi:10.1086/320609

84. Kalume F, Yu FH, Westenbroek RE, Scheuer T, Catterall WA. Reduced sodium current in Purkinje neurons from Nav1.1 mutant mice: implications for ataxia in severe myoclonic epilepsy in infancy. J Neurosci (2007) 27:11065-74. doi:10.1523/JNEUROSCI.2162-07.2007

85. Yu FH, Mantegazza M, Westenbroek RE, Robbins CA, Kalume F, Burton $\mathrm{KA}$, et al. Reduced sodium current in GABAergic interneurons in a mouse 
model of severe myoclonic epilepsy in infancy. Nat Neurosci (2006) 9:1142-9. doi:10.1038/nn1754

86. Scheffer IE, Zhang YH, Jansen FE, Dibbens L. Dravet syndrome or genetic (generalized) epilepsy with febrile seizures plus? Brain Dev (2009) 31:394-400. doi:10.1016/j.braindev.2009.01.001

87. Volkers L, Kahlig KM, Verbeek NE, Das JH, van Kempen MJ, Stroink H, et al. Nav 1.1 dysfunction in genetic epilepsy with febrile seizures-plus or Dravet syndrome. Eur J Neurosci (2011) 34:1268-75. doi:10.1111/j.1460-9568.2011. 07826.x

88. Xu XJ, Zhang YH, Sun HH, Liu XY, Wu HS, Wu XR. Phenotype and SCN1A gene mutation screening in 39 families with generalized epilepsy with febrile seizures plus. Zhonghua Er Ke Za Zhi (2012) 50:580-6. doi:10.3760/cma.j.issn. 0578-1310.2012.08.006

89. Touma M, Joshi M, Connolly MC, Grant PE, Hansen AR, Khwaja O, et al. Whole genome sequencing identifies SCN2A mutation in monozygotic twins with Ohtahara syndrome and unique neuropathologic findings. Epilepsia (2013) 54:e81-5. doi:10.1111/epi.12137

90. Oliva MK, McGarr TC, Beyer BJ, Gazina E, Kaplan DI, Cordeiro L, et al. Physiological and genetic analysis of multiple sodium channel variants in a model of genetic absence epilepsy. Neurobiol Dis (2014) 67:180-90. doi:10.1016/j.nbd. 2014.03.007

91. Hirose S, Scheffer IE, Marini C, De Jonghe P, Andermann E, Goldman AM, et al. SCN1A testing for epilepsy: application in clinical practice. Epilepsia (2013) 54:946-52. doi:10.1111/epi.12168

92. Weiss LA, Escayg A, Kearney JA, Trudeau M, MacDonald BT, Mori M, et al. Sodium channels SCN1A, SCN2A and SCN3A in familial autism. Mol Psychiatry (2003) 8:186-94. doi:10.1038/sj.mp.4001241

93. Sanders SJ, Murtha MT, Gupta AR, Murdoch JD, Raubeson MJ, Willsey AJ, et al. De novo mutations revealed by whole-exome sequencing are strongly associated with autism. Nature (2012) 485:237-41. doi:10.1038/nature10945

94. O’Roak BJ, Vives L, Girirajan S, Karakoc E, Krumm N, Coe BP, et al. Sporadic autism exomes reveal a highly interconnected protein network of de novo mutations. Nature (2012) 485:246-50. doi:10.1038/nature10989

95. Cestèle S, Labate A, Rusconi R, Tarantino P, Mumoli L, Franceschetti S, et al. Divergent effects of the T1174S SCN1A mutation associated with seizures and hemiplegic migraine. Epilepsia (2013) 54:927-35. doi:10.1111/epi.12123

96. Van Poppel K, Patay Z, Roberts D, Clarke DF, McGregor A, Perkins FF, et al. Mesial temporal sclerosis in a cohort of children with SCN1A gene mutation. J Child Neurol (2012) 27:893-7. doi:10.1177/0883073811435325

97. Gella A, Segura M, Durany N, Pfuhlmann B, Stober G, Gawlik M. Is ankyrin a genetic risk factor for psychiatric phenotypes? BMC Psychiatry (2011) 11:103. doi:10.1186/1471-244X-11-103

98. Dedman A, McQuillin A, Kandaswamy R, Sharp S, Anjorin A, Gurling H. Sequencing of the ANKYRIN 3 gene (ANK3) encoding ankyrin G in bipolar disorder reveals a non-conservative amino acid change in a short isoform of ankyrin G. Am J Med Genet B Neuropsychiatr Genet (2012) 159B:328-35. doi:10.1002/ajmg.b.32030

99. Logue MW, Solovieff N, Leussis MP, Wolf EJ, Melista E, Baldwin C, et al. The ankyrin-3 gene is associated with posttraumatic stress disorder and externalizing comorbidity. Psychoneuroendocrinology (2013) 38:2249-57. doi:10.1016/j. psyneuen.2013.04.013

100. Leussis MP, Berry-Scott EM, Saito M, Jhuang H, de Haan G, Alkan O, et al. The ANK3 bipolar disorder gene regulates psychiatric-related behaviors that are modulated by lithium and stress. Biol Psychiatry (2013) 73:683-90. doi:10.1016/j.biopsych.2012.10.016

101. Yuan A, Yi Z, Wang Q, Sun J, Li Z, Du Y, et al. ANK3 as a risk gene for schizophrenia: new data in Han Chinese and meta analysis. Am J Med Genet B Neuropsychiatr Genet (2012) 159b:997-1005. doi:10.1002/ajmg.b.32112

102. Cruz DA, Weaver CL, Lovallo EM, Melchitzky DS, Lewis DA. Selective alterations in postsynaptic markers of chandelier cell inputs to cortical pyramidal neurons in subjects with schizophrenia. Neuropsychopharmacology (2009) 34:2112-24. doi:10.1038/npp.2009.36

103. Roussos P, Katsel P, Davis KL, Bitsios P, Giakoumaki SG, Jogia J, et al. Molecular and genetic evidence for abnormalities in the nodes of Ranvier in schizophrenia. Arch Gen Psychiatry (2012) 69:7-15. doi:10.1001/archgenpsychiatry. 2011.110

104. Morgan AR, Hamilton G, Turic D, Jehu L, Harold D, Abraham R, et al. Association analysis of 528 intra-genic SNPs in a region of chromosome 10 linked to late onset Alzheimer's disease. Am J Med Genet B Neuropsychiatr Genet (2008) 147B:727-31. doi:10.1002/ajmg.b.30670

105. Santuccione AC, Merlini M, Shetty A, Tackenberg C, Bali J, Ferretti MT, et al. Active vaccination with ankyrin $\mathrm{G}$ reduces $\beta$-amyloid pathology in APP transgenic mice. Mol Psychiatry (2013) 18:358-68. doi:10.1038/mp.2012.70

106. Griswold AJ, Ma D, Sacharow SJ, Robinson JL, Jaworski JM, Wright HH, et al. A de novo $1.5 \mathrm{Mb}$ microdeletion on chromosome 14q23.2-23.3 in a patient with autism and spherocytosis. Autism Res (2011) 4:221-7. doi:10. 1002/aur.186

107. Parkinson NJ, Olsson CL, Hallows JL, McKee-Johnson J, Keogh BP, NobenTrauth K, et al. Mutant beta-spectrin 4 causes auditory and motor neuropathies in quivering mice. Nat Genet (2001) 29:61-5. doi:10.1038/ng710

108. Higuchi M, Iwata N, Matsuba Y, Takano J, Suemoto T, Maeda J, et al. Mechanistic involvement of the calpain-calpastatin system in Alzheimer neuropathology. FASEB J (2012) 26:1204-17. doi:10.1096/fj.11-187740

109. Peterson C, Vanderklish P, Seubert P, Cotman C, Lynch G. Increased spectrin proteolysis in fibroblasts from aged and Alzheimer donors. Neurosci Lett (1991) 121:239-43. doi:10.1016/0304-3940(91)90694-O

110. Seubert P, Larson J, Oliver M, Jung MW, Baudry M, Lynch G. Stimulation of NMDA receptors induces proteolysis of spectrin in hippocampus. Brain Res (1988) 460:189-94.

111. Siman R, Noszek JC, Kegerise C. Calpain I activation is specifically related to excitatory amino acid induction of hippocampal damage. J Neurosci (1989) 9:1579-90.

112. Lise S, Clarkson Y, Perkins E, Kwasniewska A, Sadighi Akha E, Schnekenberg RP, et al. Recessive mutations in SPTBN2 implicate beta-III spectrin in both cognitive and motor development. PLoS Genet (2012) 8:e1003074. doi:10.1371/journal.pgen.1003074

113. Davis JQ, Lambert S, Bennett V. Molecular composition of the node of Ranvier: identification of ankyrin-binding cell adhesion molecules neurofascin (mucin+/third FNIII domain-) and NrCAM at nodal axon segments. J Cell Biol (1996) 135:1355-67. doi:10.1083/jcb.135.5.1355

114. Kriebel M, Metzger J, Trinks S, Chugh D, Harvey RJ, Harvey K, et al. The cell adhesion molecule neurofascin stabilizes axo-axonic GABAergic terminals at the axon initial segment. J Biol Chem (2011) 286:24385-93. doi:10.1074/jbc. M110.212191

115. Zonta B, Desmazieres A, Rinaldi A, Tait S, Sherman DL, Nolan MF, et al. A critical role for neurofascin in regulating action potential initiation through maintenance of the axon initial segment. Neuron (2011) 69:945-56. doi:10. 1016/j.neuron.2011.02.021

116. Howell OW, Rundle JL, Garg A, Komada M, Brophy PJ, Reynolds R. Activated microglia mediate axoglial disruption that contributes to axonal injury in multiple sclerosis. J Neuropathol Exp Neurol (2010) 69:1017-33. doi:10.1097/NEN. 0b013e3181f3a5b1

117. Kawamura N, Yamasaki R, Yonekawa T, Matsushita T, Kusunoki S, Nagayama S, et al. Anti-neurofascin antibody in patients with combined central and peripheral demyelination. Neurology (2013) 81:714-22. doi:10.1212/WNL. 0b013e3182alaa9c

118. Mathey EK, Derfuss T, Storch MK, Williams KR, Hales K, Woolley DR, et al. Neurofascin as a novel target for autoantibody-mediated axonal injury. J Exp Med (2007) 204:2363-72. doi:10.1084/jem.20071053

119. Liu H, Focia PJ, He X. Homophilic adhesion mechanism of neurofascin, a member of the L1 family of neural cell adhesion molecules. J Biol Chem (2011) 286:797-805. doi:10.1074/jbc.M110.180281

120. Sakurai K, Migita O, Toru M, Arinami T. An association between a missense polymorphism in the close homologue of L1 (CHL1, CALL) gene and schizophrenia. Mol Psychiatry (2002) 7:412-5. doi:10.1038/sj.mp.4000973

121. Gilabert-Juan J, Varea E, Guirado R, Blasco-Ibáñez JM, Crespo C, Nácher J. Alterations in the expression of PSA-NCAM and synaptic proteins in the dorsolateral prefrontal cortex of psychiatric disorder patients. Neurosci Lett (2012) 530:97-102. doi:10.1016/j.neulet.2012.09.032

122. Angeloni D, Lindor NM, Pack S, Latif F, Wei MH, Lerman MI. CALL gene is haploinsufficient in a 3p-syndrome patient. Am J Med Genet (1999) 86 482-5. doi:10.1002/(SICI) 1096-8628(19991029)86:5<482::AID-AJMG15>3. $0 . \mathrm{CO} ; 2-\mathrm{L}$

123. Drumheller T, McGillivray BC, Behrner D, MacLeod P, McFadden DE, Roberson J, et al. Precise localisation of $3 \mathrm{p} 25$ breakpoints in four patients with the 3p-syndrome. J Med Genet (1996) 33:842-7. doi:10.1136/jmg.33.10.842 
124. Riegel M, Baumer A, Jamar M, Delbecque K, Herens C, Verloes A, et al. Submicroscopic terminal deletions and duplications in retarded patients with unclassified malformation syndromes. Hum Genet (2001) 109:286-94. doi:10.1007/s004390100585

125. Frints SG, Marynen P, Hartmann D, Fryns JP, Steyaert J, Schachner M, et al. CALL interrupted in a patient with non-specific mental retardation: gene dosage-dependent alteration of murine brain development and behavior. Hum Mol Genet (2003) 12:1463-74. doi:10.1093/hmg/ddg165

126. Kizhatil K, Wu YX, Sen A, Bennett V. A new activity of doublecortin in recognition of the phospho-FIGQY tyrosine in the cytoplasmic domain of neurofascin. J Neurosci (2002) 22:7948-58.

127. Whittard JD, Sakurai T, Cassella MR, Gazdoiu M, Felsenfeld DP. MAP kinase pathway-dependent phosphorylation of the L1-CAM ankyrin binding site regulates neuronal growth. Mol Biol Cell (2006) 17:2696-706. doi:10.1091/mbc. E06-01-0090

128. Gil OD, Sakurai T, Bradley AE, Fink MY, Cassella MR, Kuo JA, et al. Ankyrin binding mediates L1CAM interactions with static components of the cytoskeleton and inhibits retrograde movement of L1CAM on the cell surface. J Cell Biol (2003) 162:719-30. doi:10.1083/jcb.200211011

129. Maness PF, Schachner M. Neural recognition molecules of the immunoglobulin superfamily: signaling transducers of axon guidance and neuronal migration. Nat Neurosci (2007) 10:19-26. doi:10.1038/nn0207-263b

130. Brusse E, de Koning I, Maat-Kievit A, Oostra BA, Heutink P, van Swieten JC. Spinocerebellar ataxia associated with a mutation in the fibroblast growth factor 14 gene (SCA27): a new phenotype. Mov Disord (2006) 21:396-401. doi:10.1002/mds.20708

131. van Swieten JC, Brusse E, de Graaf BM, Krieger E, van de Graaf R, de Koning $\mathrm{I}$, et al. A mutation in the fibroblast growth factor 14 gene is associated with autosomal dominant cerebellar ataxia [corrected]. Am J Hum Genet (2003) 72:191-9. doi:10.1086/345488

132. Wang C, Hoch EG, Pitt GS. Identification of novel interaction sites that determine specificity between fibroblast growth factor homologous factors and voltage-gated sodium channels. JBiol Chem (2011) 286:24253-63. doi:10.1074/ jbc.M111.245803

133. Turner CA, Calvo N, Frost DO, Akil H, Watson SJ. The fibroblast growth factor system is downregulated following social defeat. Neurosci Lett (2008) 430:147-50. doi:10.1016/j.neulet.2007.10.041

134. Mallei A, Shi B, Mocchetti I. Antidepressant treatments induce the expression of basic fibroblast growth factor in cortical and hippocampal neurons. Mol Pharmacol (2002) 61:1017-24. doi:10.1124/mol.61.5.1017

135. Maragnoli ME, Fumagalli F, Gennarelli M, Racagni G, Riva MA. Fluoxetine and olanzapine have synergistic effects in the modulation of fibroblast growth factor 2 expression within the rat brain. Biol Psychiatry (2004) 55:1095-102. doi:10.1016/j.biopsych.2004.02.003

136. Turner CA, Akil H, Watson SJ, Evans SJ. The fibroblast growth factor system and mood disorders. Biol Psychiatry (2006) 59:1128-35. doi:10.1016/j.biopsych. 2006.02.026

137. Wang Q, Bardgett ME, Wong M, Wozniak DF, Lou J, McNeil BD, et al. Ataxia and paroxysmal dyskinesia in mice lacking axonally transported FGF14. Neuron (2002) 35:25-38. doi:10.1016/S0896-6273(02)00744-4

138. Wozniak DF, Xiao M, Xu L, Yamada KA, Ornitz DM. Impaired spatial learning and defective theta burst induced LTP in mice lacking fibroblast growth factor 14. Neurobiol Dis (2007) 26:14-26. doi:10.1016/j.nbd.2006.11.014

139. Xiao M, Bosch MK, Nerbonne JM, Ornitz DM. FGF14 localization and organization of the axon initial segment. Mol Cell Neurosci (2013) 56:393-403. doi:10.1016/j.mcn.2013.07.008

140. Insel TR, Voon V, Nye JS, Brown VJ, Altevogt BM, Bullmore ET, et al. Innovative solutions to novel drug development in mental health. Neurosci Biobehav Rev (2013) 37:2438-44. doi:10.1016/j.neubiorev.2013.03.022

141. McMahon FJ, Insel TR. Pharmacogenomics and personalized medicine in neuropsychiatry. Neuron (2012) 74:773-6. doi:10.2147/PGPM.S60747

142. Chène P. Drugs targeting protein-protein interactions. ChemMedChem (2006) 1:400-11. doi:10.1002/cmdc.200600004

143. Stoilova-McPhie S, Ali S, Laezza F. Protein:protein interactions as new target for ion channel drug discovery. Austin J Pharmacol Ther (2013) 1:1-5.

144. Akram ON, Degraff DJ, Sheehan JH, Tilley WD, Matusik RJ, Ahn JM, et al. Tailoring peptidomimetics for targeting protein-protein interactions. Mol Cancer Res (2014) 12(7):967-78. doi:10.1158/1541-7786.MCR-13-0611
145. Whitby LR, Boger DL. Comprehensive peptidomimetic libraries targeting protein-protein interactions. Acc Chem Res (2012) 45:1698-709. doi:10.1021/ $\operatorname{ar} 300025 n$

146. Elefsinioti A, Sarac OS, Hegele A, Plake C, Hubner NC, Poser I, et al. Large-scale de novo prediction of physical protein-protein association. Mol Cell Proteomics (2011) 10:M111.010629. doi:10.1074/mcp.M111.010629

147. Zhang QC, Petrey D, Deng L, Qiang L, Shi Y, Thu CA, et al. Structure-based prediction of protein-protein interactions on a genome-wide scale. Nature (2012) 490:556-60. doi:10.1038/nature11503

148. Nero TL, Morton CJ, Holien JK, Wielens J, Parker MW. Oncogenic protein interfaces: small molecules, big challenges. Nat Rev Cancer (2014) 14:248-62. doi: $10.1038 / \operatorname{nrc} 3690$

149. Yuriev E, Ramsland PA. Latest developments in molecular docking: 2010-2011 in review. J Mol Recognit (2013) 26:215-39. doi:10.1002/jmr.2266

150. Heist RS, Fain J, Chinnasami B, Khan W, Molina JR, Sequist LV, et al. Phase I/II study of AT-101 with topotecan in relapsed and refractory small cell lung cancer. J Thorac Oncol (2010) 5:1637-43. doi:10.1097/JTO.0b013e3181e8f4dc

151. Hwang JJ, Kuruvilla J, Mendelson D, Pishvaian MJ, Deeken JF, Siu LL, et al. Phase I dose finding studies of obatoclax (GX15-070), a small molecule panBCL-2 family antagonist, in patients with advanced solid tumors or lymphoma. Clin Cancer Res (2010) 16:4038-45. doi:10.1158/1078-0432.CCR-10-0822

152. Li H, Xiao H, Lin L, Jou D, Kumari V, Lin J, et al. Drug design targeting protein-protein interactions (PPIs) using multiple ligand simultaneous docking (MLSD) and drug repositioning: discovery of raloxifene and bazedoxifene as novel inhibitors of IL-6/GP130 interface. J Med Chem (2014). 57:632-41. doi:10.1021/jm401144z

153. Cimarosti H, Kantamneni S, Henley JM. Ischaemia differentially regulates GABA(B) receptor subunits in organotypic hippocampal slice cultures. Neuropharmacology (2009) 56:1088-96. doi:10.1016/j.neuropharm.2009.03.007

154. Kulinskii VI, Mikhel'son GV. Additivity and independence of neuroprotective effects of GABAA and GABAB receptor agonists in complete global cerebral ischemia. Bull Exp Biol Med (2000) 130:772-4. doi:10.1007/BF02681942

155. Benke D. GABAB receptor trafficking and interacting proteins: targets for the development of highly specific therapeutic strategies to treat neurological disorders? Biochem Pharmacol (2013) 86:1525-30. doi:10.1016/j.bcp. 2013.09.016

156. Ottmann C. Small-molecule modulators of 14-3-3 protein-protein interactions. Bioorg Med Chem (2013) 21:4058-62. doi:10.1016/j.bmc.2012.11.028

157. Bertaso F, Zhang C, Scheschonka A, de Bock F, Fontanaud P, Marin P, et al. PICK1 uncoupling from mGluR7a causes absence-like seizures. Nat Neurosci (2008) 11:940-8. doi:10.1038/nn.2142

158. Shirley RL, Walter NA, Reilly MT, Fehr C, Buck KJ. Mpdz is a quantitative trait gene for drug withdrawal seizures. Nat Neurosci (2004) 7:699-700. doi:10.1038/nn1271

159. Sharma SC, Rupasinghe CN, Parisien RB, Spaller MR. Design, synthesis, and evaluation of linear and cyclic peptide ligands for PDZ10 of the multiPDZ domain protein MUPP1. Biochemistry (2007) 46:12709-20. doi:10.1021/ bi7008135

160. Cho E, Fogel BL. A family with spinocerebellar ataxia type 5 found to have a novel missense mutation within a SPTBN2 spectrin repeat. Cerebellum (2013) 12:162-4. doi:10.1007/s12311-012-0408-0

Conflict of Interest Statement: The authors declare that the research was conducted in the absence of any commercial or financial relationships that could be construed as a potential conflict of interest.

Received: 21 April 2014; accepted: 06 August 2014; published online: 21 August 2014. Citation: Hsu W-CJ, Nilsson CL and Laezza F (2014) Role of the axonal initial segment in psychiatric disorders: function, dysfunction, and intervention. Front. Psychiatry 5:109. doi: 10.3389/fpsyt.2014.00109

This article was submitted to Molecular Psychiatry, a section of the journal Frontiers in Psychiatry.

Copyright (c) $2014 \mathrm{Hsu}$, Nilsson and Laezza. This is an open-access article distributed under the terms of the Creative Commons Attribution License (CC BY). The use, distribution or reproduction in other forums is permitted, provided the original author(s) or licensor are credited and that the original publication in this journal is cited, in accordance with accepted academic practice. No use, distribution or reproduction is permitted which does not comply with these terms. 